\title{
Effects of a predatory starfish on substrate colonization by a dominant mussel
}

\author{
Fernando J. Hidalgo ${ }^{1, *}$, Fausto N. Firstater ${ }^{1}$, Betina J. Lomovasky ${ }^{1,2}$, \\ Oscar O. Iribarne ${ }^{1,2}$ \\ ${ }^{1}$ Laboratorio de Ecología, Departamento de Biología (FCEyN), Universidad Nacional de Mar del Plata, \\ CC 573 Correo Central, B7600WAG Mar del Plata, Argentina \\ ${ }^{2}$ Concejo Nacional de Investigaciones Científicas y Tecnológicas (CONICET), Av. Rivadavia 1917, C1033AAJ Buenos Aires, \\ Argentina
}

\begin{abstract}
The pressure exerted by consumers has generally been considered to be among the main factors affecting the structure and processes in marine communities. Here, we assessed the effects of the predatory starfish Heliaster helianthus on substrate colonization by the dominant mussel Semimytilus algosus in a rocky intertidal area of the central Peruvian coast. We conducted 3 experiments: exclusions of starfish (1) from the edge of mussel beds, (2) from areas on bare substrate and (3) from areas surrounding recruitment mediators (i.e. branched macroalgae). The exclusion of $H$. helianthus resulted in increased cover of $S$. algosus in the 3 experiments. However, the colonization of the available space by $S$. algosus in the absence of starfish was more evident when facilitated by recruitment mediators or by migration from the edge of mussel beds than when colonization occurred during succession starting from bare substrate. By the end of the study period, however, increased $S$. algosus abundance, which coincided with the end of the cold phase (La Niña) of the El Niño-Southern Oscillation, overwhelmed the effects of starfish. We suggest that periodic oceanographic fluctuations are also important in controlling community dynamics in Peruvian rocky intertidal zones, highlighting the variation in the relative importance of top-down versus bottom-up control when different temporal scales are considered.
\end{abstract}

KEY WORDS: Starfish · Heliaster helianthus $\cdot$ Predation $\cdot$ Semimytilus algosus $\cdot$ Rocky intertidal Peru

Resale or republication not permitted without written consent of the publisher

\section{INTRODUCTION}

The pressure exerted by consumers has generally been considered to be among the main factors affecting the structure and processes in marine communities (e.g. Duffy \& Hay 2001). It is determined by, and interacts with, other physical (e.g. upwelling intensity, environmental stresses) and biological (e.g. recruitment, competence) processes and can affect the rates of succession (e.g. Benedetti-Cecchi 2000), primary productivity (e.g. Silliman \& Zieman 2001), diversity patterns (e.g. Paine 1966, Estes \& Palmisano 1974), abundance and distribution of species (e.g. Yamada \& Boulding 1996), or competitive interactions (e.g. Paine 1966).
Key demonstrations of the effects of predation come from the works of Paine $(1966,1974)$. He found that predation by starfish controls the competitively dominant mussels in the low shore. By preventing mussels to monopolize the substratum, starfish not only increase the diversity of species attached to the primary substrate (Paine 1971, 1974), but can also negatively affect mussel-associated organisms that depend on the structurally complex habitat provided by the mussel matrix (see Tokeshi \& Romero 1995a). These effects were later documented in other intertidal systems around the world (e.g. North America, Paine 1974; New Zealand, Paine 1971; Chile, Paine et al. 1985) and were also extended to encompass other intertidal predators (e.g. Menge 1976, Menge \& 
Lubchenco 1981, Castilla \& Durán 1985). Later works (e.g. Robles \& Desharnais 2002), however, demonstrated that rather than predation alone, prey abundances are determined by the interplay between varying rates of predation and prey production (both recruitment and growth), indicating that the predator control paradigm may not be as general as previously thought.

Along the Pacific coast of South America, the starfish Heliaster helianthus is one of the most abundant intertidal predators (e.g. Castilla 1981, Paine et al. 1985, Tokeshi et al. 1989). It is a voracious predator of a wide variety of organisms, with mussels generally accounting for the larger bulk of the prey consumed (e.g. Paine et al. 1985, Tokeshi et al. 1989, Navarrete \& Manzur 2008). Work conducted at about 32 to $33^{\circ} \mathrm{S}$ (central Chile) show that $H$. helianthus is a keystone predator due to its effects on beds of the dominant mussel Perumytilus purpuratus (Castilla 1981, Paine et al. 1985). In central Peru $\left(\sim 11^{\circ} \mathrm{S}\right), P$. purpuratus is being competitively displaced by the mussel Semimytilus algosus to a narrow belt in the upper portion of the mid-intertidal zone (Tokeshi 1999, p. 385-387, Tokeshi \& Romero 1995a). S. algosus is a fast-recruiting, fastgrowing mussel that occupies a more extensive zone than that occupied by $P$. purpuratus, from the midintertidal downwards, forming a multilayered belt (Tokeshi et al. 1989). The 2 geographically separated populations of $H$. helianthus from Chile and Peru show different patterns of prey utilization, which reflect the relative abundance of the different prey species: on the Peruvian coast, $S$. algosus is more frequently consumed than $P$. purpuratus, while the situation is reversed in Chile (Tokeshi et al. 1989). Studies on diet and feeding behaviour of $H$. helianthus on rocky benches of central Peru (e.g. Tokeshi 1989, Tokeshi et al. 1989, Tokeshi \& Romero 1995b) have led to the assumption of a similar predatory role of that played $\sim 2400 \mathrm{~km}$ to the south (see Tokeshi 1999, p. 385-387). However, differences in ecological or life-history characteristics of the 2 mussel species may result in differences in the ability of starfish to control them. In addition, more recent field experiments showed that, while intertidal consumers can control community structure south of $32^{\circ} \mathrm{S}$, populations seem recruitment limited to the north (at least up to $29^{\circ} \mathrm{S}$; Navarrete et al. 2005). North of that range, differences in circulation patterns, upwelling intensity and identity of species that dominate the rocky substrate suggest that the role of predation as a key structuring force may be different, although the lack of experimental studies impede robust conclusions (see Vasquez et al. 1998, Fernández et al. 2000). Furthermore, the impacts of the cold (or La Niña, LN) and warm (or El Niño, EN) phases of the El Niño-Southern Oscillation (ENSO) are stronger towards northern Chile and Peru and can modulate other biological interactions (Vasquez et al. 1998, Fernández et al. 2000, Arntz et al. 2006, Thiel et al. 2007) and may change the relative importance of top-down versus bottom-up control of the community structure (see Vinueza et al. 2006), adding further uncertainty on the effects of predation in structuring those intertidal communities.

Given this background, the aim of the present paper was to evaluate the effects of Heliaster helianthus on its sessile prey in a protected rocky shore of central Peru. We focused particularly on the effects of $H$. helianthus on colonization of the substrate by the dominant mussel Semimytilus algosus at different successional stages. Since, by the end of our study, LN intensified on the Peruvian coast (see 'Results'), we were able to evaluate the change in the relative importance of top-down versus bottom-up controls of the community structure.

\section{MATERIALS AND METHODS}

Study site. The study was conducted from June 2005 to May 2008 on a rocky shore located south of Ancón Bay $\left(11^{\circ} 46^{\prime} \mathrm{S}, 77^{\circ} 11^{\prime} \mathrm{W}\right.$; central Peru). Most of the work was conducted on the wave-protected, eastern side of a small island ( 1 ha) located $70 \mathrm{~m}$ from the coast. Experiments were deployed in an intertidal area of $\sim 120 \mathrm{~m}^{2}$ along the island. Throughout this area, 2 rock benches $\left(\sim 10 \mathrm{~m}^{2}\right.$ each, separated by $\left.30 \mathrm{~m}\right)$ were maintained without experimental disturbance and were used to assess the temporal dynamics in the organisms' abundance. Another rocky bench of similar size, located $100 \mathrm{~m}$ in front of the island and relatively more exposed to wave action, was also selected for surveys of the organisms' abundance and was not used for manipulations. Tides in the area are semi-diurnal and have a maximum range of from -0.17 to $1.21 \mathrm{~m}$ relative to Chart Datum (Dirección de Hidrografía y Navegación 2006).

Reports on the ENSO. In order to associate the observed patterns with the main oceanographic fluctuations on the Peruvian coast, monthly values of sea surface temperature (SST) anomalies and the southern oscillation index (SOI) were obtained from the Climate Prediction Center of the NOAA (www.cpc. ncep.noaa.gov/data/indices/) for the study period. Positive SST anomalies, measured at Niño 3.4 Region $\left(5^{\circ} \mathrm{N}\right.$ to $5^{\circ} \mathrm{S}, 120$ to $\left.170^{\circ} \mathrm{W}\right)$ are related to $\mathrm{EN}$, whereas negative values are related to LN (Trenberth 1997). The SOI index is calculated as the sea level airpressure differential between Tahiti $\left(150^{\circ} \mathrm{W}\right)$ and Darwin $\left(150^{\circ} \mathrm{E}\right)$. It represents the general state of the tropical Pacific and does not vary according to lati- 
tude. Negative SOI values, which occur during EN events, reflect lower pressure over Tahiti and movement of warm West Pacific waters to the eastern Pacific; in an analogous way, positive SOI values occur during LN (see Navarrete et al. 2002). In addition, descriptive monthly reports on the state of the ENSO, based on SST anomalies, mixed layer conditions, equatorial zonal winds and SOI were obtained from the National Climatic Data Center of the NOAA (www.ncdc.noaa.gov/sotc/) for the study period.

Starfish abundance and diet. Starfish abundance was quantified by counting and measuring (total diameter, from ray tip to ray tip; $\mathrm{cm}$ ) the animals present in randomly placed quadrats $(\mathrm{N}=30$ to $90 ; 1 \times 1 \mathrm{~m})$ at the mid- and low intertidal levels of the whole protected side of the island in spring (October 2005 and November 2007) and fall (April 2006, May 2007 and May 2008) months (during neutral ENSO and LN conditions). One-way ANOVAs were then used to test for differences in densities and sizes among dates (Zar 1999). To examine feeding, all prey individuals held and being consumed by a starfish were collected during each survey. The inner buccal cavity was also inspected, and all prey items found were identified, counted and measured (see Tokeshi 1989). After food collection, starfish were returned to their original positions. All surveys were conducted during daylight hours and mostly during intermediate to low tide periods, even though tidal conditions do not affect the results of dietary observations (see Tokeshi 1989).

Starfish effects on sessile organisms. Starfish effects on sessile organisms were evaluated using cageexclusion experiments. Three experiments were conducted at the mid-low intertidal level (i.e. in the lower midlittoral zone, sensu Paredes 1974). The first experiment (hereafter termed 'exclusions on mussel beds') allowed us to test the effect of Heliaster helianthus on the development of Semimytilus algosus patches and was conducted on the edge of areas already covered by mussels. To exclude starfish from these areas, we used stainless steel mesh cages $(25 \times 25 \times 5 \mathrm{~cm}$; length $\times$ width $\times$ height; mesh size $=1.1 \mathrm{~cm}$ ) anchored to the substrate with a central bolt. The mesh size and the irregular fitting of the cage border onto the rock surface allowed most herbivores (e.g. sea urchins, snails) and small predators (e.g. the crab Acanthocyclus gayi) to enter the exclusion cages. Manipulation controls were cages identical in shape but with 2 opposite sides open; controls were uncaged plots marked at the corners with epoxy putty. Initial mussel cover in the experimental plots was variable (mean \pm SD: $22.89 \pm$ $13.70 \%)$, but was not different among treatments (1-way ANOVA on log-transformed data, $F_{2,24}=0.06$, $\mathrm{p}=0.94)$. The entire experiment was run during neu- tral ENSO conditions, starting in October 2005, with 9 replicates per treatment; however, by May 2006 many of the cages were lost, obligating us to reduce analysis to only 5 replicates at the end of the experiment. Thus, the experiment was run for only $7 \mathrm{mo}$, from spring to fall. Percent cover of mussels was estimated using the point intercept method with a quadrat with 100 evenly spaced points. Since we were interested in evaluating whether mussel patches expand or shrink in the presence or absence of consumers over the course of the experiment, a repeated-measures ANOVA was used to compare percent cover data among treatments and between dates (Quinn \& Keough 2002). This test was selected because temporal data (i.e. cover at the beginning and at the end of the experiment) were not independent (they were taken from the same plot). Percent cover data was square root transformed to meet parametric assumptions (Zar 1999).

When starfish were excluded from mussel beds, mussel cover increased in exclusions and had little variation in controls (see 'Results'), though some control plots were left devoid of sessile organisms, indicating that predation can affect the development of established mussel patches and can even provide free space by eliminating the main space holders. Because re-colonization of disturbed patches during secondary succession can be affected by predation (e.g. Dayton 1971, Paine \& Levin 1981), a second experiment (hereafter termed 'exclusions on bare rock') was conducted on denuded areas and allowed us to test the effects of starfish on the development of the community starting from bare substrate. Exclusions, manipulation controls and total controls were constructed as described above, but cages were slightly smaller to prevent loss due to wave action $(22 \times 22 \times 5 \mathrm{~cm}$; length $\times$ width $\times$ height; mesh size $=1.1 \mathrm{~cm}$ ); 10 replicates of each treatment were used. This experiment was run from November 2006 to May 2008 (i.e. spring 2006 to fall 2008), and the percent cover of organisms was recorded in April, August (during neutral ENSO conditions) and November 2007 (during LN) and in May 2008 (when neutral ENSO conditions began to re-establish). The data were compared among treatments and dates with repeated-measures ANOVA (Quinn \& Keough 2002).

Our previous observations suggested that Semimytilus algosus might find refuge when settling among the intertidal corticated algae Prionitis decipiens (see also Moreno 1995), since the examination of $P$. decipiens plants in areas apparently devoid of mussels on bare rock showed that $S$. algosus individuals were present attached to the base and thalli of the algae (mean number of $S$. algosus individuals attached to 8 plants $=82.5$; range $=13$ to 173 individuals plant ${ }^{-1}$ ). Thus, the third experiment (hereafter 
termed 'exclusions on algae') tested whether starfish can control the expansion of mussels from the algae to the substrate. For this, 27 adult fronds of $P$. decipiens $(\sim 10 \mathrm{~cm}$ of height) were selected at the same intertidal level at which the other experiments were conducted. Nine plants were chosen for each of 3 treatments: exclusions, controls and experimental controls. In the exclusions, plastic mesh cages of $30 \times$ $30 \times 15 \mathrm{~cm}$ (length $\times$ width $\times$ height; mesh size $=$ $2 \mathrm{~cm}$ ) were fixed to the rock leaving the algae in the centre of the plot. As mentioned above, manipulation controls used cages of the same size but with openings on 2 opposite sides, and controls were uncaged plots marked at the corners with epoxy putty. The experiment was run from November 2006 to November 2007 (spring 2006 to spring 2007), and the percent cover of mussels on the substrate was measured in April, August (during neutral ENSO conditions) and November 2007 (during LN), The data were compared among treatments and dates with repeatedmeasures ANOVA (Quinn \& Keough 2002). We also compared the rate of mussel clump development when it was facilitated by $P$. decipiens and when it started from bare substrate, by measuring the percent cover of mussels in exclusions of both experiments on each sampling date. Repeated-measures ANOVA was used to test for significant differences (Quinn \& Keough 2002). In all cases, log or square root transformations were applied to the data when parametric assumptions were not met (Zar 1999).

Temporal dynamics of dominant sessile species cover. To account for natural variations in the abundance of dominant sessile species, we recorded the cover of sessile organisms in the 3 areas that were not experimentally manipulated (Area 1,2 and $3 ; \sim 10 \mathrm{~m}^{2}$ each; see study site description). Areas 1 and 3 were the rocky benches (separated by $30 \mathrm{~m}$ ) located off the island, and Area 2 was the rocky bench located in front of the island (see study site description). Each area was photographed completely with a digital camera every $\sim 6 \mathrm{mo}$, from June 2005 (winter) to May 2008 (fall); usually 1 to 3 digital pictures taken from a distance of 1.7 to $4 \mathrm{~m}$ were necessary to capture the whole intertidal area (from the high intertidal to the lowest tide mark). To estimate percent cover of identifiable organisms (i.e. Semimytilus algosus, red filamentous and red corticated algae), 10 transects perpendicular to the shore, extending from the lower limit of the high intertidal (barnacle zone) to the upper limit of the low intertidal, were overlapped on the digital images of the whole area. Each transect had 10 equally spaced dots, and the percent cover was estimated by the point intercept method. Data from each area were compared among sampling dates with 1-way ANOVAs; square root or log transformations were used when data did not meet parametric assumptions (Zar 1999).

\section{RESULTS}

\section{Reports on the ENSO}

The qualitative monthly reports of the NOAA, based on SST anomalies, SOI, mixed layer conditions and equatorial zonal winds showed shifting ENSO conditions throughout the study period, which did not totally develop in LN or EN, except from October 2007, when LN conditions intensified and persisted, to March 2008 (Fig. 1A). Monthly SST anomalies and SOI values matched this description (Fig. 1B).
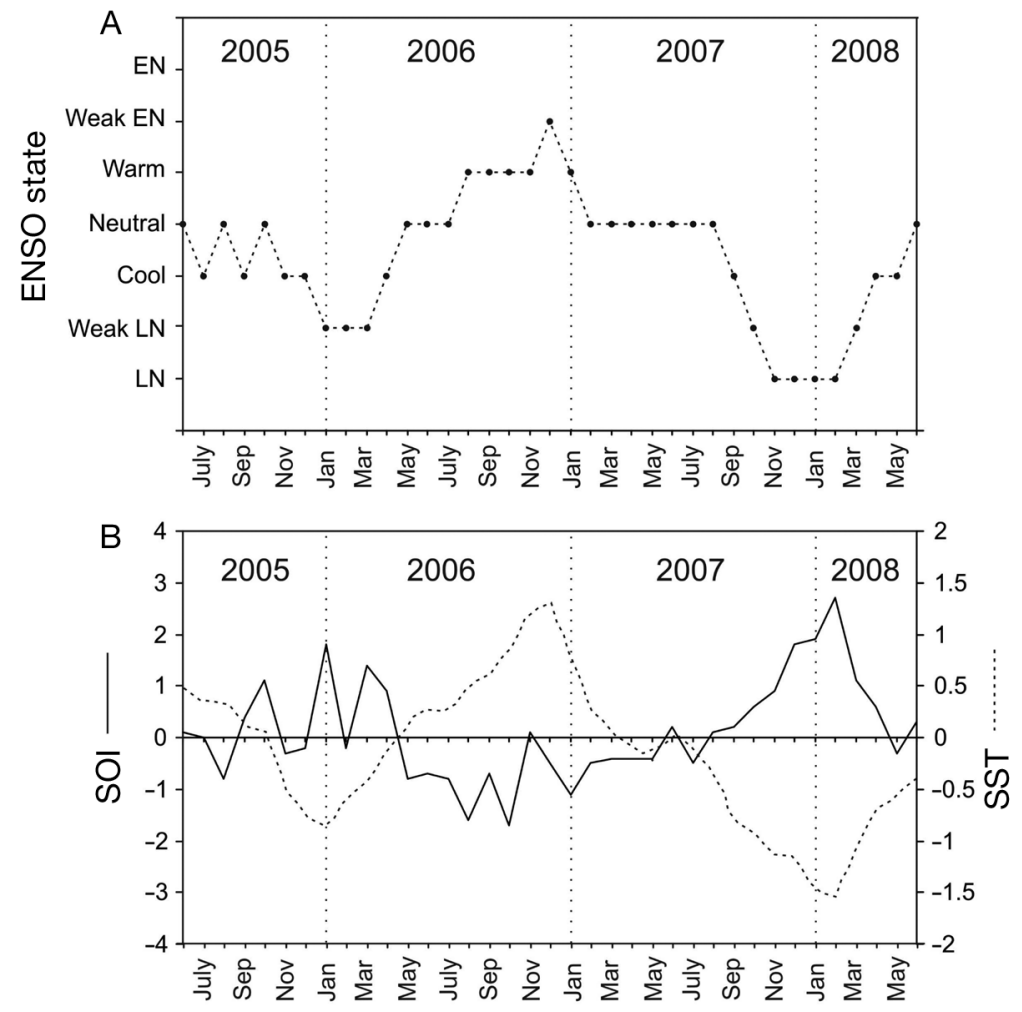

Time

Fig. 1. (A) Qualitative representation of the state of the El Niño-Southern Oscillation (ENSO) throughout the study period based on sea surface temperature (SST) anomalies, the southern oscillation index (SOI), equatorial zonal winds and mixed layer conditions. 'Cool' and 'Warm' refer to negative and positive thermal anomalies, respectively, relative to the neutral phase of the ENSO. EL: El Niño; LN: La Niña. (B) SST anomaly in the Niño 3.4 region, and SOI for the study period 


\section{Starfish abundance and diet}

The density of Heliaster helianthus ranged between 0.31 and 1.07 individuals $\mathrm{m}^{-2}$, being more abundant during the samplings of October 2005 (spring) and April 2006 (fall), both during neutral ENSO conditions, than in May 2007 (fall, neutral ENSO conditions), November 2007 (spring, LN conditions) and May 2008 (fall, neutral ENSO conditions; 1 -way ANOVA, $F_{4,232}=$ 10.26, p < 0.001; Fig. 2). Starfish sizes ranged between 12 and $28 \mathrm{~cm}$ (total diameter), and those collected in April 2006 were smaller than those of the other sampling dates (1-way ANOVA, $F_{4,133}=7.69$, p $<0.001$; Fig. 2). More than 17 prey species were observed in the diets of the $138 \mathrm{H}$. helianthus individuals analyzed (Table 1). Mussels were the main components of its diet, Semimytilus algosus being more frequently consumed than Perumytilus purpuratus (Table 1). Although the proportion of species consumed varied among sampling dates, mussels were always the main component of the diet (Table 1). In May 2008, almost the only prey consumed was $S$. algosus (Table 1).

\section{Starfish effects on sessile organisms}

The exclusion of Heliaster helianthus from small experimental areas at the mid-low intertidal level resulted in varying rates of colonization of the space by the mussel Semimytilus algosus. When starfish were excluded from mussel beds (from October 2005 to May 2006), the percent cover of $S$. algosus increased from $\sim 10$ to $60 \%$ in the exclusions, while it remained near 10 to $15 \%$ in the other treatments, yielding a significant treatment by sampling date interaction (repeatedmeasures ANOVA on square-root-transformed data, $F_{2,12}=17.53, \mathrm{p}<0.001$; Fig. 3).

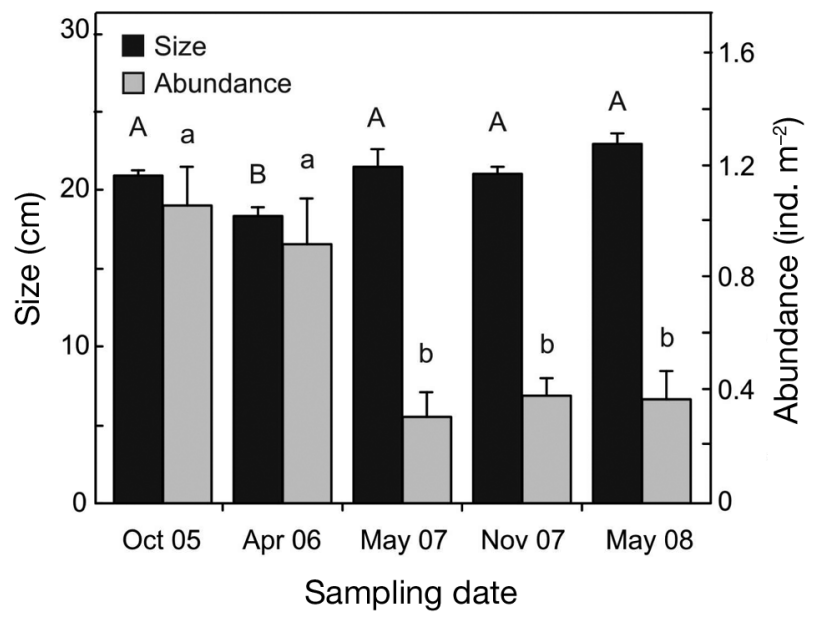

Fig. 2. Heliaster helianthus. Size (total diameter, from ray tip to ray tip; $\mathrm{cm}$ ) and abundance (ind. $\mathrm{m}^{-2}$ ) on different sampling dates. Data are means \pm SE. Different upper case and lower case letters indicate significant differences $(\mathrm{p}<0.05)$ in sizes and abundance, respectively, between dates after 1-way ANOVAs

Table 1. Percentages of individuals of each prey species consumed by Heliaster helianthus on each sampling date. Total number of individuals analyzed $=138$; total number of individuals with food in the stomach $=96$

\begin{tabular}{|c|c|c|c|c|c|c|c|}
\hline Prey species & Oct 2005 & Apr 2006 & May 2007 & Nov 2007 & May 2008 & $\begin{array}{c}\text { Total (all } \\
\text { dates pooled) }\end{array}$ & $\begin{array}{l}\text { Length range } \\
\text { (mm) }\end{array}$ \\
\hline Mytilids & & & & & & 86.67 & \\
\hline Semimytilus algosus & 50.63 & 40.91 & 64.28 & 35.96 & 93.86 & 56.87 & $1-32.2$ \\
\hline Perumytilus purpuratus & 45.57 & 39.39 & 21.42 & 34.21 & 0 & 29.79 & $1.5-31$ \\
\hline Barnacles & & & & & & 3.96 & \\
\hline Austromegabalanus psittacus & 0 & 4.54 & 3.57 & 8.77 & 1.75 & 3.33 & $14-39$ \\
\hline Chthamalid barnacles & 0.63 & 0 & 0 & 0.88 & 0 & 0.43 & $6-6.4$ \\
\hline Balanoid barnacles & 0.63 & 0 & 0 & 0 & 0 & 0.21 & 8.99 \\
\hline Gastropods & & & & & & 8.75 & \\
\hline Tegula atra & 0 & 6.06 & 0 & 12.28 & 0 & 3.75 & $3.5-30.2$ \\
\hline Prisogaster niger & 0 & 0 & 0 & 2.63 & 3.51 & 1.46 & $9.6-12.1$ \\
\hline Scurria spp. & 1.90 & 7.57 & 0 & 0 & 0 & 1.67 & $4.7-15.5$ \\
\hline Scurria plana & 0 & 0 & 0 & 0.88 & 0 & 0.21 & 14.6 \\
\hline Fissurella limbata & 0 & 0 & 3.57 & 2.63 & 0 & 0.83 & $6.5-8.8$ \\
\hline Fissurella sp. & 0 & 0 & 3.57 & 0 & 0 & 0.21 & 45 \\
\hline Siphonaria lessoni & 0.63 & 0 & 0 & 0 & 0 & 0.21 & 6.88 \\
\hline Echinolittorina peruviana & 0 & 0 & 3.57 & 0 & 0 & 0.21 & 6.59 \\
\hline Crassilabrum crassilabrum & 0 & 0 & 0 & 0.88 & 0 & 0.21 & 22 \\
\hline Chitons & & & & & & 0.42 & \\
\hline Chiton granosus & 0 & 1.51 & 0 & 0 & 0 & 0.21 & 37.2 \\
\hline Tonicia sp. & 0 & 0 & 0 & 0 & 0.88 & 0.21 & 33.1 \\
\hline Porcellanid crabs & 0 & 0 & 0 & 0.88 & 0 & 0.21 & 4 \\
\hline
\end{tabular}




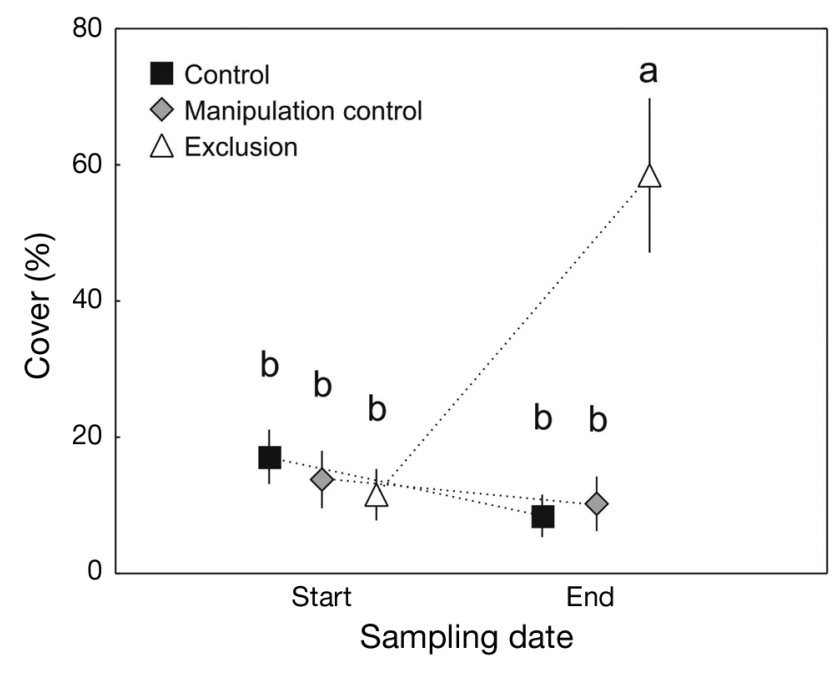

Fig. 3. Semimytilus algosus. Percent cover (mean \pm SE) of mussels in controls $(\square)$, manipulation controls $(\diamond)$ and exclusions $(\Delta)$ at the beginning and end of the experiment in which starfish were excluded from mussel beds. Different letters indicate significant differences among treatments and dates (beginning and end of the experiment) after repeatedmeasures ANOVA

During the exclusions on bare rock, the main sessile organisms that colonized the experimental plots were barnacles (Jehlius cirratus and Notochthamalus scabrosus), Ulva spp., red filamentous algae (Polysiphonia spp. and Ceramiun spp.), Gelidium sp. and other red corticated algae (Chondracanthus chamissoi, Gigartina glomerata and Prionitis decipiens), and the mussel Semimytilus algosus (Fig. 4). Barnacle cover was always higher in the exclusions $\left(F_{2,27}=3.68, \mathrm{p}=0.039\right.$; Fig. 4A), with the lowest coverage in May $2008\left(F_{3,81}=\right.$ 5.08, $p=0.003$; Fig. 4A). Macroalga cover did not show differences among treatments (Fig. 4C-F), though they did show differences among sampling dates (Gelidium sp.: $F_{3,81}=10.30, \mathrm{p}<0.001$, Fig. 4C; Ulva spp.: $F_{3,81}=20.77, \mathrm{p}<0.001$, Fig. 4D; red corticated algae: $F_{3,81}=16.67, \mathrm{p}<0.001$, Fig. $4 \mathrm{E}_{\text {; }}$ red filamentous algae: $F_{6,81}=52.97, \mathrm{p}<0.001$, Fig. $\left.4 \mathrm{~F}\right)$. The cover of $S$. algosus was in general low $(<10 \%)$ until November 2007, when it was higher in exclusions than in the other treatments (Fig. 4B). However, S. algosus occupied the experimental areas almost completely by May 2008 (when neutral ENSO conditions began to reestablish), yielding a significant sampling date by treatment interaction $\left(F_{6,81}=7.79, \mathrm{p}<0.001\right.$; Fig. $\left.4 \mathrm{~B}\right)$.

In the exclusions on algae, Semimytilus algosus cover of the primary substrate increased form April to November $2007\left(F_{2,48}=27.53, \mathrm{p}<0.001\right.$; Fig. 5), and was higher in exclusions than in the other treatments (repeated-measures ANOVA on log-transformed data; $F_{2,24}=55.06, \mathrm{p}<0.001$; Fig. 5). Furthermore, development of mussel aggregations in starfish exclusions were faster when facilitated by Prionitis decipiens than when started from bare rock (repeated-measures ANOVA; date: $F_{2,34}=40.79, \mathrm{p}<0.001$; treatment: $F_{1,17}=86.86, \mathrm{p}<0.001$; Fig. 6).

\section{Temporal dynamics of dominant sessile species cover}

The cover of the dominant sessile species showed different patterns through time in the 3 areas (Fig. 7). For Semimytilus algosus, the only change in common for the 3 areas was the elevated abundance at the end of the study period (i.e. May 2008). Prior to this, percent cover decreased over time in Area 1, increased gradually over time in Area 2 and remained low through time in Area 3 (Fig. 7A, Table 2). The percent cover of red filamentous algae remained relatively low $(<10 \%)$ over time in the 3 areas, increasing in November 2007 (during LN) and remaining relatively abundant until May 2008 (Fig. 7B, Table 2). Red corticated algae showed low coverage during the whole study period in Area 1; in Areas 2 and 3, however, coverage was variable over time, being lowest in May 2008 (Fig. 7C, Table 2).

\section{DISCUSSION}

The results of this work demonstrated that Heliaster helianthus can affect the abundance of the dominant mussel Semimytilus algosus in a Peruvian rocky intertidal, validating previous assumptions based on its foraging behaviour and its well-documented effects on the mussel Perumytilus purpuratus in central Chile. Starfish effects were more evident when space colonization by $S$. algosus occurred when recruitment mediators were present or by lateral migration from mussel aggregations, than when successions started from the bare substrate. Nevertheless, the increased abundance of $S$. algosus at the end of the study overwhelmed the effects of starfish. We discuss here the possible causes of the elevated mussel abundance at the end of our study, which coincided with the end of the cold phase of the ENSO, and the significance of such an episode on understanding the predator-prey relationship in Peruvian rocky shores.

Heliaster helianthus is one of the most abundant predatory starfish in the intertidal zone on the Pacific temperate coast of South America (Castilla 1981, Tokeshi et al. 1989). Our data agree with previous studies, indicating that it is a generalist predator able to consume a broad range of prey species, mussels being the main component of its diet (Tokeshi et al. 1989, Navarrete \& Manzur 2008). Our results also showed that Semimytilus algosus was more frequently 


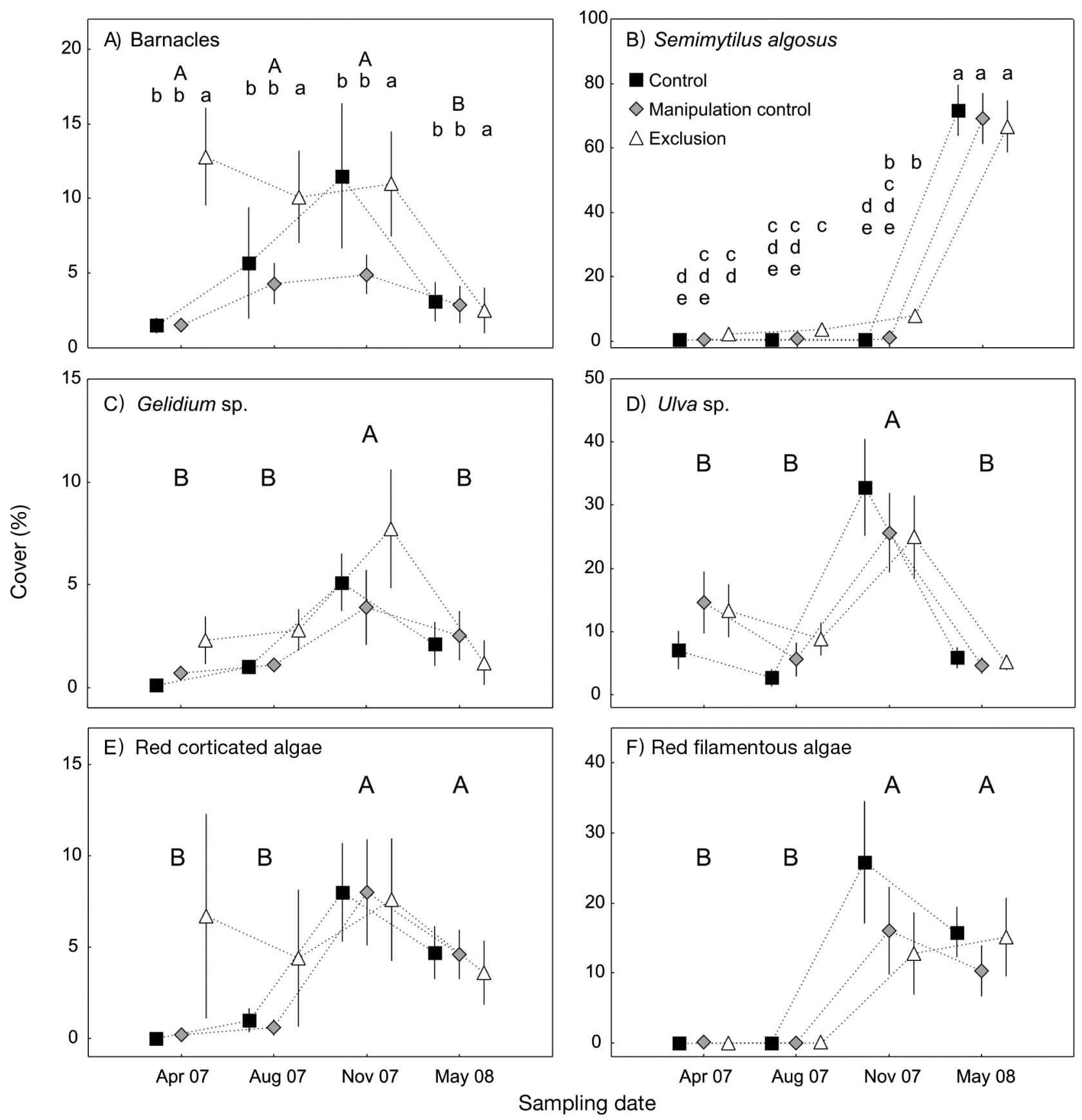

Fig. 4. Percent cover (mean \pm SE) of the main sessile organisms within controls $(\square)$, manipulation controls $(\diamond)$ and exclusions $(\Delta)$ on the different sampling dates. Different uppercase and lowercase letters indicate significant differences $(p<0.05)$ between sampling dates and treatments, respectively (repeated-measures ANOVA; Tukey honestly significant difference [HSD] tests

for post hoc comparisons). Data of Semimytilus algosus and red corticated algae were log transformed for the analysis

consumed than Perumytilus purpuratus, affirming previous studies on the Peruvian coast (e.g. Tokeshi 1989, Tokeshi et al. 1989) and contradicting studies on $H$. helianthus from Chile, the preferred prey of which is apparently $P$. purpuratus (Navarrete \& Manzur 2008). The variation in the relative proportion of prey consumed by $H$. helianthus along the latitudinal gradi- ent from Chile to Peru may be due to differences in prey preferences or with the relative abundance of the different prey species (see Tokeshi et al. 1989, Navarrete \& Manzur 2008). Although our data might indicate that prey consumption on the Peruvian coast relates to prey availability, since $S$. algosus was almost the only prey consumed when its intertidal abundance was at a 


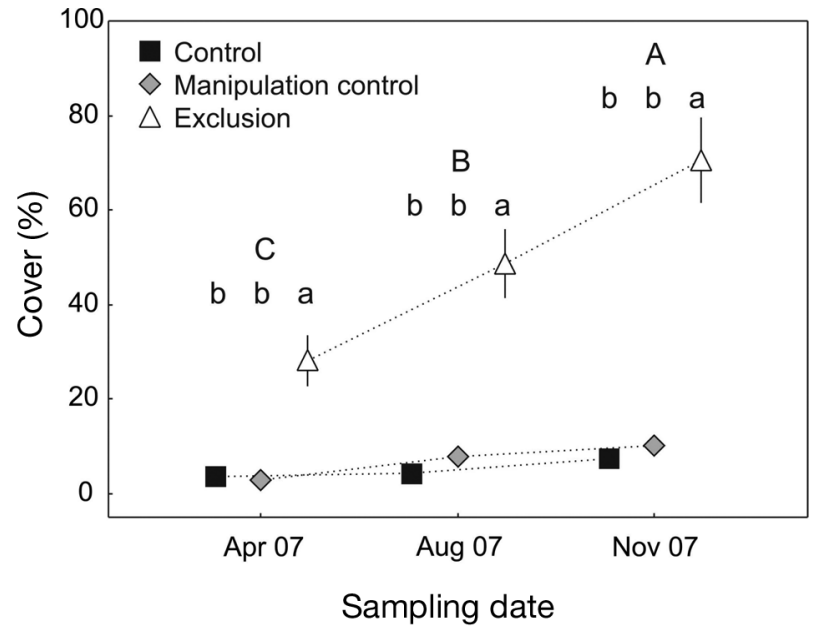

Fig. 5. Semimytilus algosus. Percent cover (mean \pm SE) of mussels in controls ( $\square)$, manipulation controls $(\diamond)$ and exclusions $(\Delta)$ deployed over Prionitis decipiens plants. Different uppercase and lowercase letters indicate significant differences $(\mathrm{p}<0.05)$ between sampling dates and treatments, respectively (repeated-measures ANOVA on log-transformed data; Tukey HSD tests for post hoc comparisons)

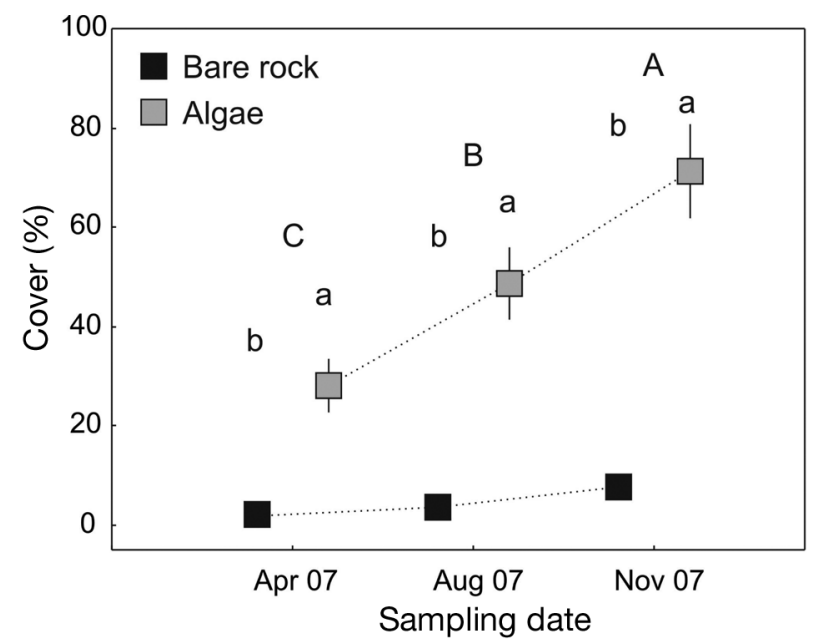

Fig. 6. Semimytilus algosus. Percent cover (mean \pm SE) of mussels in starfish exclusions conducted on bare rock and on Prionitis decipiens fronds. Different uppercase and lowercase letters indicate significant differences $(\mathrm{p}<0.05)$ between sampling dates and treatments (bare rock or algal fronds), respectively (repeated-measures ANOVA on log-transformed data; Tukey HSD tests for post hoc comparisons)

maximum (in May 2008); further work is still necessary to resolve whether the dietary compositions of $H$. helianthus from Chile and Peru vary in relation to prey preference or prey availability.

Work conducted between 32 and $29^{\circ} \mathrm{S}$ has shown that Heliaster helianthus can control the abundance of Perumytilus purpuratus around $\sim 32$ to $33^{\circ} \mathrm{S}$ (e.g. Paine et al. 1985, Navarrete et al. 2005), while the limited
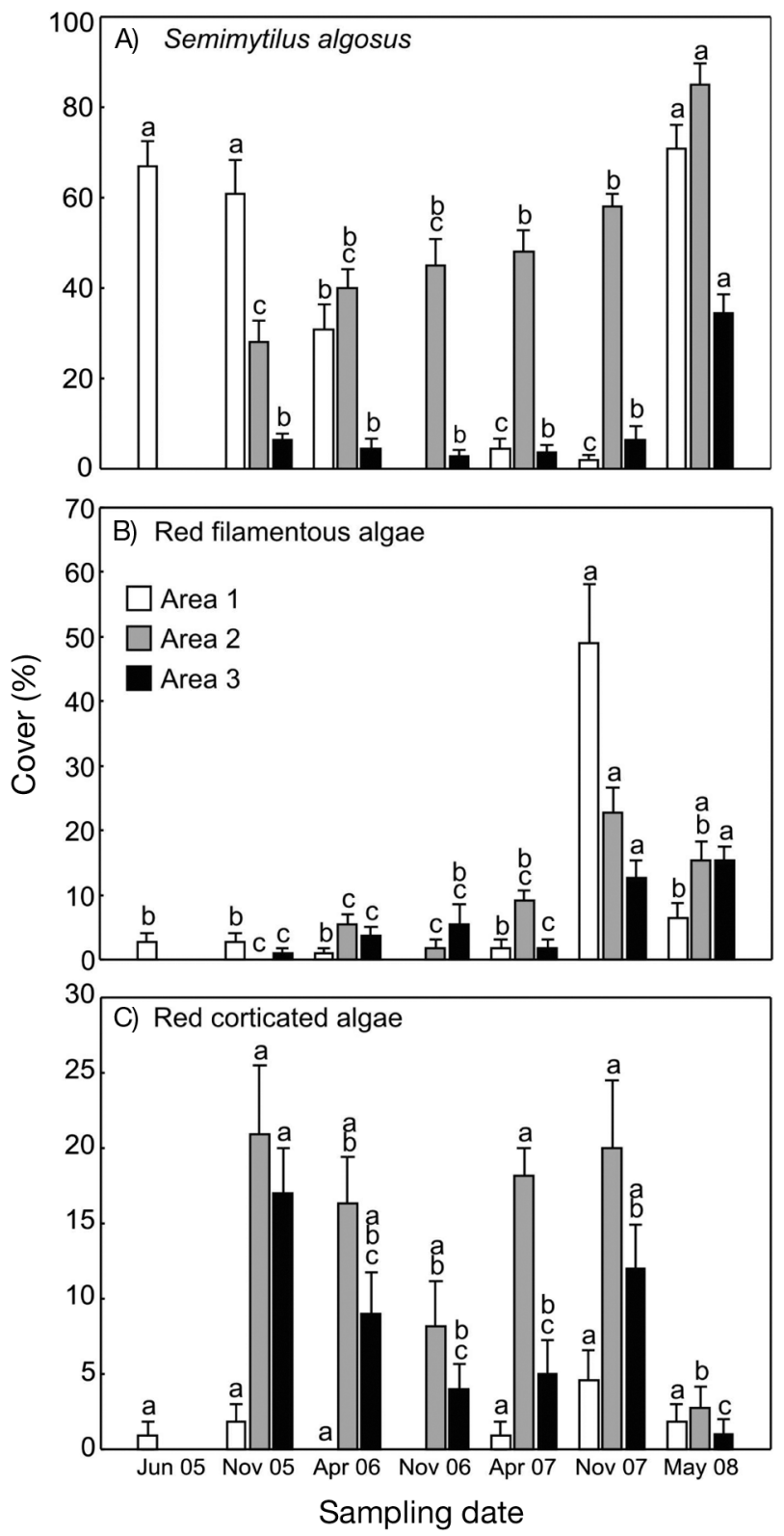

Fig. 7. Percent cover (mean \pm SE) of: (A) Semimytilus algosus, (B) red filamentous algae and (C) red corticated algae in Areas 1,2 and 3 on different sampling dates. Different letters indicate significant differences $(p<0.05)$ in percent cover between dates in each area after 1-way ANOVAs

recruitment of prey populations to the north diminishes the role of predation as a structuring force (Navarrete et al. 2005). Comparatively less is known about the effects of predation north of that range, although the identity of the main space holders, differences in circulation patterns, upwelling intensity and the oceanographic shifts related to the ENSO suggest that the role of predation may be different (see Vasquez et al. 1998, Fernández et al. 2000). Based on data on its foraging behaviour and on its well-documented effects 
Table 2. Results of 1-way ANOVAs testing for temporal differences in the cover of Semimytilus algosus, red filamentous algae and red corticated algae in the 3 areas where the temporal dynamics of the cover of sessile organisms were recorded. Square root transformation was applied to data of mussel cover in Areas 1 and 3; red filamentous algae, in Area 1; and red corticated algae, in Area 3

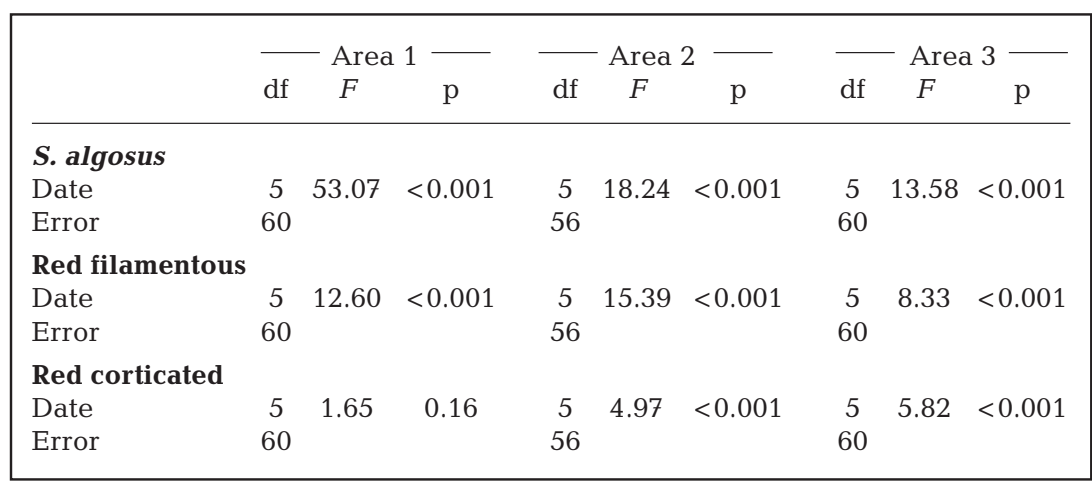

in central Chile, $H$. helianthus has been suggested to control the abundance of Semimytilus algosus (see Tokeshi \& Romero 1995a, Tokeshi 1999), and our experimental results can now validate these assumptions, since the exclusion of starfish from small areas in the mid-low intertidal zone resulted in increasing abundances of $S$. algosus. This effect was variable and dependent on the initial state of the community. When $H$. helianthus was excluded from the edge of $S$. algosus beds, percent cover of mussels increased from 10 to $60 \%$ in 7 mo. When starfish were excluded from the bare rock, the development of the community was apparently much slower. During the exclusions on bare rock, the cover of barnacles and $S$. algosus increased within starfish exclusions, with significant differences occurring 5 and 12 mo after the beginning of the experiment, respectively. Nevertheless, their coverage in the exclusions was low by those dates (on average $\sim 12$ and $10 \%$, for barnacles and S. algosus, respectively). This result contradicts the findings of previous experiments on these rocky shores, which indicated that barnacles covered $\sim 80 \%$ of denuded areas within 3 mo, while $S$. algosus occupied $100 \%$ of the area after 1 yr (Tokeshi \& Romero 1995a). The experiment by Tokeshi \& Romero (1995a) was conducted on cleared areas within the $S$. algosus bed; thus, walls provided by surrounding mussels may have impeded access to the experimental plots of grazers that are capable of bulldozing or crushing settlers (e.g. Holmes et al. 2005). Conversely, during our exclusions on bare rock, the experimental plots were not surrounded by mussels, and the mesh size of our cages allowed the entrance of gastropods or sea urchins that could have negatively affected young settlers due to their grazing activity. The lack of differences in the cover of algae among treatments further indicates that grazers entered the exclusions. Therefore, although the exclusions on mussel beds and the exclusions on bare rock were initiated at different times, thus limiting our ability to quantitatively compare rates of mussel colonization between the 2 experiments, these results lend further credence to those of Tokeshi \& Romero (1995a), which indicate that space colonization by $S$. algosus occurs faster by lateral migration from mussel aggregations than by either recruitment of larvae onto the substrate or by drifting individuals detached from the substrate elsewhere. Also, when starfish were excluded from corticated macroalgae that already had attached mussels (i.e. exclusions on macroalgae), substrate colonization by mussels was faster than that which occurs starting from the bare substrate (i.e. exclusions on bare substrate). It is known that filamentous or structurally complex substrata can act as recruitment mediators (Suchanek 1978, Navarrete \& Castilla 1990), and this is important for the colonization of different mussel species, including $S$. algosus (see Moreno 1995, Tokeshi \& Romero 1995a). Mussels that recruit on macroalgae may find refuge from predation within the branches (Moreno 1995) and can then grow further, or new settlers may recruit facilitated by the algae or the byssal threads of the former mussels (e.g. Suchanek 1978, Navarrete \& Castilla 1990). Without predation by $H$. helianthus, growth and new recruitment allow mussels to colonize the primary substratum and to spread out forming larger clumps (see Moreno 1995). Together, these results showed that $H$. helianthus can influence the development of $S$. algosus assemblages; this is even more evident when the presence of recruitment mediators allows rapid colonization of the space.

Though Heliaster helianthus seems to affect the abundance of Semimytilus algosus, the single experiment running at the end of the study period (May 2008) showed that the effect of starfish was overwhelmed by a disproportionate increment in the abundance of $S$. algosus by that date. The increased abundance was evident, not only in the different treatments of the second experiment, but also in the 3 areas where the dynamics in the abundance of $S$. algosus were followed, and coincided with the end of the LN episode on the Peruvian coast. Although the available data for $S$. algosus indicate that recruitment generally occurs year round and is highly variable in space and time (see Tarazona et al. 1985, Navarrete et al. 2002, 2008, Belapatiño Candela 2007), it has also been shown that $S$. algosus recruitment is enhanced during LN (Ramos 
et al. 2000) by different mechanisms acting individually or synergistically. First, upwelling intensification during LN elevates nutrient availability (see Arntz et al. 2006), potentially improving growing conditions for S. algosus, although upwelling and offshore currents would be expected to export larvae offshore, lowering recruitment (e.g. Connolly \& Roughgarden 1999). Similarly, environmental variables related to LN might have also influenced the increased abundance of red filamentous macroalgae observed in November 2007, which are known to facilitate the recruitment of S. algosus (see Tokeshi \& Romero 1995a). In addition, predation rates by starfish might be reduced during LN because of lower water temperature (see Sanford 1999 for the case of Pisaster ochraceus and Mytilus spp.), allowing mussels to survive and colonize the intertidal in great numbers. Also, grazing pressure may be reduced, enhancing macroalgal growth and further facilitating mussel recruitment. In addition, the increased abundance of $S$. algosus does not seem to be related to a reduction in the density of $H$. helianthus, since this decline was already observed in May 2007 ( $\sim 4$ mo before a fall in the SST and rise in the SOI indicated the onset of LN). Furthermore, the second experiment (i.e. exclusions on bare rock) ran when starfish densities were reduced, and mussel cover was low all through the experiment (from April to November 2007 mussel cover only increased up to $10 \%$ in the exclusions); however, with the same starfish densities, but during LN conditions (i.e. from November 2007 to May 2008), mussel cover increased from 10 to $80 \%$ in all treatments. Therefore, environmental signatures related to LN may trigger a number of processes that are difficult to individualize, but may ultimately affect organisms' abundance. However, we cannot assign the incremented mussel abundance to LN alone, since this was not evaluated, and the variation in $S$. algosus recruitment may also be a characteristic of its life history (see Robles 1997 for other mussel species) or related to more local environmental changes (Navarrete et al. 2002, 2008, Arntz et al. 2006).

Massive recruitment of prey may swamp predators because a large number of juveniles may survive long enough to grow and find a size refuge to escape predation, establishing them in the intertidal (Dayton 1971, Paine et al. 1985, McClintock \& Robnett 1986, Robles 1997 ) and occasionally generating alternative community states (Paine \& Trimble 2004). Nevertheless, Heliaster helianthus is able to consume all Semimytilus algosus sizes (see Tokeshi 1989), so it is unlikely that this state of high mussel abundance persists at our study site. In central Chile $\left(33^{\circ} \mathrm{S}\right)$, for example, experimental removals of $H$. helianthus have resulted in increasing cover of Perumytilus purpuratus, but when starfish return to the experimental areas, the commu- nity converges toward the undisturbed state, since $P$. purpuratus cannot find a size refuge against predation by $H$. helianthus (Paine et al. 1985). Although we could not check the progress of mussel beds after May 2008, we speculate that continuous predation by $H$. helianthus at our study site would allow $S$. algosus to return to its former abundance.

Together, our results demonstrated that Heliaster helianthus affects the abundance of the dominant space holder Semimytilus algosus in the rocky intertidal of central Peru, supporting previous assumptions based on the superb foraging capacity of $H$. helianthus and on their recognized effects in central Chile (see Tokeshi \& Romero 1995a, Tokeshi 1999). The effects of $H$. helianthus on $S$. algosus were more evident when mussel colonization of the substrate was mediated by filamentous or complex structures or when mussels colonized the available space by lateral migration from aggregations of conspecifics, since recovery of the community was slower when starting from bare substrate. Moreover, the effect of starfish was overwhelmed by the end of the study period because of the incremented abundance of mussels at the study site. Our data, collected at a single site on the central Peruvian coast, do not supply a reason for the elevated mussel abundance, though this might be related to the cold phase of the ENSO, which reached the Peruvian coast at the end of the study period; nevertheless, natural variation in $S$. algosus recruitment may just be a characteristic of its life history or may be related to local environmental changes. Processes affecting the structure and dynamics of intertidal communities vary over spatial and temporal scales. In general, community patterns observed at local or small temporal scales can be determined by top-down factors (e.g. predation, competition), though differences in community patterns observed at larger temporal or spatial scales could be driven by bottom-up factors, such as differences in nutrient or larval input or in upwelling intensity (e.g. Dayton et al. 1992, Menge 2000). Even though we could not disentangle the causes of the elevated mussel abundance at the end of the study period, our results highlight the variation in the relative importance of top-down versus bottom-up control of community structure when different temporal scales are considered. As pointed out by Tokeshi (1999), despite the fact that biological factors (such as predation) play a primary role in the control of Peruvian rocky intertidal communities, periodic oceanographic fluctuations are also important in maintaining the dynamics of this system at longer temporal scales.

Acknowledgements. We express our gratitude to J. Tarazona for providing the laboratory facilities; and to E. Ramos, P. Gallegos and A. Gamarra for helping us in the field and with the 
logistics in Peru. We also thank L. Romero for demonstrating his interest in our work by sharing his knowledge about the Peruvian intertidal. We thank the people of the Balneario de La Marina for giving us access to the study sites. This manuscript benefited greatly from the comments and suggestions made by J. Pearse and two anonymous reviewers. The present study was conducted and financed within the framework of the EU project CENSOR (Climate Variability and El Niño Southern Oscillation: Impacts for Natural Resources and Management, Contract 511071) and is part of the doctoral dissertation of F.H.

\section{LITERATURE CITED}

Arntz WE, Gallardo VA, Gutiérrez D, Isla E and others (2006) El Niño and similar perturbation effects on the benthos of the Humboldt, California, and Benguela Current upwelling ecosystems. Adv Geosci 6:243-265

Belapatiño Candela AO (2007) Variabilidad del asentamiento larval de mitílidos en bahía Independencia, Pisco-Perú, durante el período 1996-2003. Bachelor thesis, Universidad Nacional Mayor de San Marcos, Lima

Benedetti-Cecchi L (2000) Predicting direct and indirect interactions during succession in a mid-littoral rocky shore assemblage. Ecol Monogr 70:45-72

Castilla JC (1981) Perspectivas de investigación en estructura y dinámica de comunidades intermareales rocosas de Chile central. II. Depredadores de alto nivel trófico. Med Am 5:190-215

Castilla JC, Durán LR (1985) Human exclusion from the rocky intertidal zone of central Chile: the effects on Concholepas concholepas (Gastropoda). Oikos 45:391-399

Connolly SR, Roughgarden J (1999) Theory of marine communities: competition, predation, and recruitment-dependent interaction strength. Ecol Monogr 69:277-296

> Dayton PK (1971) Competition, disturbance, and community organization: the provision and subsequent utilization of space in a rocky intertidal community. Ecol Monogr 41:351-389

Dayton PK, Tegner MJ, Parnell PE, Edwards PB (1992) Temporal and spatial patterns of disturbance and recovery in a kelp forest community. Ecol Monogr 62:421-445

Dirección de Hidrografía y Navegación (2006) Tabla de mareas 2006. Puertos de la costa del Perú, Océano PacíficoAmérica del Sur. Ministerio de Defensa, Marina de Guerra del Perú, Lima

Duffy JE, Hay ME (2001) The ecology and evolution of marine consumer-prey interactions. In: Bertness MD, Gaines SD, Hay ME (eds) Marine community ecology. Sinauer Associates, Sunderland, MA, p 131-157

Estes JA, Palmisano L (1974) Sea otters: their role in structuring nearshore communities. Science 185:1058-1060

Fernández M, Jaramillo E, Marquet P, Moreno CA and others (2000) Diversity, dynamics and biogeography of Chilean benthic nearshore ecosystems: an overview and guidelines for conservation. Rev Chil Hist Nat 73:797-830

> Holmes SP, Walker G, van der Meer J (2005) Barnacles, limpets and periwinkles: the effects of direct and indirect interactions on cyprid settlement and success. J Sea Res 53:181-204

McClintock JB, Robnett TJ Jr (1986) Size selective predation by the asteroid Pisaster ochraceus on the bivalve Mytilus californianus: a cost-benefit analysis. PSZN I: Mar Ecol 7: 321-332

Menge BA (1976) Organization of the New England rocky intertidal community: role of predation, competition, and environmental heterogeneity. Ecol Monogr 46:355-393
Menge BA (2000) Top-down and bottom-up community regulation in marine rocky intertidal habitats. J Exp Mar Biol Ecol 250:257-289

> Menge BA, Lubchenco J (1981) Community organization in temperate and tropical rocky intertidal habitats: prey refuges in relation to consumer pressure gradients. Ecol Monogr 51:429-450

Moreno CA (1995) Macroalgae as a refuge from predation for recruits of the mussel Choromytilus chorus (Molina, 1782) in southern Chile. J Exp Mar Biol Ecol 191:181-193

> Navarrete SA, Castilla JC (1990) Barnacle walls as mediators of intertidal mussel recruitment: effects of patch size on the utilization of space. Mar Ecol Prog Ser 68:113-119

> Navarrete SA, Manzur T (2008) Individual- and populationlevel responses of a keystone predator to geographic variation in prey. Ecology 89:2005-2018

Navarrete SA, Broitman B, Wieters EA, Finke GR, Venegas RM, Sotomayor A (2002) Recruitment of intertidal invertebrates in the Southeast Pacific: interannual variability and the 1997-1998 El Niño. Limnol Oceanogr 47:791-802

Navarrete SA, Wieters EA, Broitman BR, Castilla JC (2005) Scales of benthic-pelagic coupling and the intensity of species interactions: from recruitment limitation to topdown control. Proc Natl Acad Sci USA 102:18046-18051

Navarrete SA, Broitman BR, Menge BA (2008) Interhemispheric comparison of recruitment to intertidal communities: pattern persistence and scales of variation. Ecology 89:1308-1322

> Paine RT (1966) Food web complexity and species diversity. Am Nat 100:65-75

Paine RT (1971) A short term experimental investigation of resource partitioning in a New Zealand rocky intertidal habitat. Ecology 52:1096-1106

Paine RT (1974) Intertidal community structure: experimental studies on the relationship between a dominant competitor and its principal predator. Oecologia 15:93-120

Paine RT, Levin SA (1981) Intertidal landscapes: disturbance and the dynamics of pattern. Ecol Monogr 51:145-178

> Paine RT, Trimble AC (2004) Abrupt community change on a rocky shore-biological mechanisms contributing to the potential formation of an alternative state. Ecol Lett 7: 441-445

Paine RT, Castilla JC, Cancino J (1985) Perturbation and recovery patterns of starfish-dominated intertidal assemblages in Chile, New Zealand and Washington State. Am Nat 125:679-691

Paredes C (1974) El modelo de zonación de la orilla rocosa del Departanemto de Lima. Rev Peru Biol 1:168-191

Quinn GP, Keough MJ (2002) Experimental design and data analysis for biologists. Cambridge University Press, Cambridge

Ramos E, Valle S, Tarazona J (2000) Variaciones del asentamiento larval de algunos bivalvos de bahía Independencia, Pisco-Perú, durante los eventos La Niña. In: Libro de Resúmenes: El evento La Niña y su impacto biológico. Universidad Nacional Mayor de San Marcos, Lima, p 79

Robles CD (1997) Changing recruitment in constant species assemblages: implications for predation theory in intertidal communities. Ecology 78:1400-1414

Robles C, Desharnais R (2002) History and current development of a paradigm of predation in rocky intertidal communities. Ecology 83:1521-1536

Sanford E (1999) Regulation of keystone predation by small changes in ocean temperature. Science 283:2095-2097

Silliman BR, Zieman JC (2001) Top-down control of Spartina alterniflora production by periwinkle grazing in a Virginia salt marsh. Ecology 82:2830-2845 
Suchanek TH (1978) The ecology of Mytilus edulis L. in exposed rocky intertidal communities. J Exp Mar Biol Ecol 31:105-120

Tarazona J, Paredes C, Romero L, Blaskovich V, Guzmán S, Sánchez S (1985) Características de la vida planctónica y colonización de los organismos bentónicos epilíticos durante el fenómeno El Niño. In: Arntz W, Landa A, Tarazona J (eds) 'El Niño', su impacto en la fauna marina. Bol Inst Mar Perú, Callao, Vol Extraordinario, p 41-49

Thiel M, Macaya EC, Acuña E, Arntz WE and others (2007) The Humboldt Current System of northern and central Chile: oceanographic processes, ecological interactions and socioeconomic feedback. Oceanogr Mar Biol Annu Rev 45:195-344

Tokeshi M (1989) Development of a foraging model for a field population of the South American sun-star Heliaster helianthus. J Anim Ecol 58:189-206

Tokeshi M (1999) Species coexistence: ecological en evolutionary perspectives. Blackwell, London

Tokeshi M, Romero L (1995a) Filling a gap: dynamics of space occupancy on a mussel-dominated subtropical rocky shore. Mar Ecol Prog Ser 119:167-176

Editorial responsibility: James McClintock, Birmingham, Alabama, USA
Tokeshi M, Romero L (1995b) Quantitative analysis of foraging behaviour in a field population of the South American sun-star Heliaster heliantus. Mar Biol 122: 297-303

Tokeshi M, Estrella C, Paredes C (1989) Feeding ecology of a size-structured predator population, the South American sun-star Heliaster helianthus. Mar Biol 100:495-505

Trenberth KE (1997) The definition of El Niño. Bull Am Meteorol Soc 78:2771-2777

Vasquez JA, Camus PA, Ojeda FP (1998) Diversity, structure and functioning of rocky coastal ecosystems in northern Chile. Rev Chil Hist Nat 71:479-499

- Vinueza LR, Branch GM, Branch ML, Bustamante RH (2006) Top-down herbivory and bottom-up El Niño effects on Galápagos rocky-shore communities. Ecol Monogr 76: 111-131

Yamada SB, Boulding EG (1996) The role of highly mobile predators in the intertidal zonation of their gastropod prey. J Exp Mar Biol Ecol 204:59-83

Zar JH (1999) Biostatistical analysis, 4th edn. Prentice-Hall, Englewood Cliffs, NJ

Submitted: September 30, 2010; Accepted: April 7, 2011 Proofs received from author(s): May 30, 2011 